\title{
Notary Role In Making The Establishment Of The Deed Of Business Cooperation In The Rembang District
}

\begin{abstract}
Zaenal Arifin ${ }^{1}$, Risky Amalia² and Aryani Witasari ${ }^{3}$
Abstract. The purpose of this study was to analyze: 1) The implementation of the Deed of Establishment of Cooperative manufacture in Rembang. 2) The role of the Notary as the maker of the Deed of Establishment of Cooperative Enterprises. 3) Barriers and solutions in the Deed of Establishment of Cooperative Development in Rembang.

The approach method in this research is juridical empirical, data sources used are primary and secondary data obtained through interviews and literature study, performed data analysis by descriptive analytic.

Results of the research results can be concluded: 1) Implementation of Creation Deed of Establishment of Cooperative in Rembang which starts with the preparation stage of formation, preparation stage meetings of formation, stage meetings of formation, stage request for approval rights of legal entities cooperatives, and the stage of issuance of the deed pendiiran and 2) As the role of Notary Deed of establishment of cooperative enterprises in Rembang is as maker deed of cooperative efforts. Notaries have the right authority / legal standing in a deed of incorporation of cooperatives. 3). Obstacles and solutions in the Deed of Establishment of Cooperative Development in Rembang of the cooperative is a member of the cooperative awareness level is still low, less managerial capacity, and limited capital resources. Barriers of Notary Public Notary is still much limited knowledge of Notary Deed Official Cooperation (PPAK) and the low interest of the Notary Deed Cooperative (NPAK) in Rembang district were registered for the Legal Entity Administration System Cooperative (SISMINBHKOP). With the state of a society, then the Office of Industry Trade Cooperatives and Small and Medium Enterprises Rembang should seek to build cooperation between the Notary in Rembang with the Agency's own cooperative.

Keywords: Deed of Establishment of Cooperative; PPAK; SISMINBHKOP
\end{abstract}

\section{Introduction}

Cooperative is a form of company organization whose main purpose is not for profit but seek the welfare of its members. As a cooperative society for the common welfare, conduct business and activities in the field along with the fulfillment of the members. Cooperatives have a significant role in preparing the joint efforts of the people who have limited economic capacity. In order to attempt to advance the position of the people who have limited economic capacity, then the Indonesian Government notice the growth and development Cooperative societies. The people in the form of a cooperative effort that promotes the principle of solidarity is a fundamental difference with other forms of business including individual based on limited liability company mainly in stock ownership and stock management is a major asset in developing the

\footnotetext{
1 Master Notary Law Student, Sutan Agung Islamic University Semarang e-mail: igazainal@gmail.com

2 Students of Master of Law, Faculty Of Law, Universitas Islam Sultan Agung email riskya300795@gmail.com

${ }^{3}$ Lecturer of Faculty of Law, Sutan Agung Islamic University Semarang
} 
cooperative as a business entity in accordance with the spirit of the Indonesian people. $^{4}$

The establishment of a cooperative is required or use a legally enforceable notarial deed is strong. With the force of law is the basis for cooperative activities, in order to have protection for the institution and its officials. Notary as a public official, is one of the organs of the State which is equipped with the legal authority to provide public services, especially in the manufacture of the authentic as perfect evidence with regard to actions in the field of civil law. ${ }^{5}$

To make an authentic deed a Notary must follow the rules set out in legislation. Act No. 30 of 2004 concerning Notary Jo. Act No. 2 of 2014 concerning Notary the legal foundation Notary, have determined step by step to do a Notary if he makes an authentic act. These steps are (among others heard the parties express their will, then read out the contents of the deed to the applicant, signed the act and others) is specifically held lawmakers to ensure that what is written in the deed it does contain what is desired the parties. ${ }^{6}$

Rapid social developments also caused the legal relations developments in society, the role of the Notary to be very complex and often very different to the prevailing regulations. Thus it seems difficult to fully define the tasks and jobs Notary. ${ }^{7}$ However, as has been described, in essence, the task of the Notary is set in writing and authentic legal relations between the parties unanimously enlist the services of a Notary. Notary of the main tasks, it can be said Notary have a daunting task of having to provide the public with the best.

Regent Rembang said economic growth in Rembang is much above the national average and provincial governments. Investors who entered in Rembang is also growing. It is expected to also be helped economic growth in Rembang. Economic growth can not be separated from the role of regional-owned enterprises as well as cooperatives. Based on this background, lifted the title Notary Role in Making the Establishment of the Deed of Business Cooperation in the Rembang District. This study tried to answer the problem of implementation of the Deed of Establishment of Cooperative Development, Role as a Notary Deed of Establishment of Cooperative Enterprises in Rembang, barriers and solutions in the Deed of Establishment of Cooperative Development in Rembang.

\section{Research methods}

The method used in this research is juridical empirical. Juridical empirical research that focuses on the behavior of individuals or communities in connection with the law. ${ }^{8}$

\footnotetext{
${ }^{4}$ Ninik Widiyanto, 1992, Koperasi dan Perkonomian Indonesia, Rineka Cipta, Jakarta, p.76.

${ }^{5}$ N.G Yudara, Notaris dan Permasalahannya (Pokok-Pokok Pemikiran Di Seputar Kedudukan dan Fungsi Notari Serta Akta Notaris Menurut Sistem Hukum Indonesia). Majalah Renvoi No. 10.34 III, Edisi 3 Maret 2006p. 72

${ }^{6}$ Tan Khong Kie (b), 2000, Buku II Studi Notarisat Serba Serbi Praktek Notaris, pbl. 1, Ikhtiar Baru Van Hoeve, Jakarta, p. 261

7 Habib Adjie, 2003, Tebaran Pemikiran Dalam Dunia Notaris dan PPAT, "Penegakan Etika Profesi Notaris Dari Perspektif Pendekatan System,'Lembaga Kajian Notaris dan PPAT Indonesia, Surabaya, p. 27

8 Soerjono Soekanto dan Sri Mamadji, 2009, Penelitian Hukum Normatif: Suatu Tinjauan Singkat, RajaGrafindo Persada, Jakarta, p.1
} 
Specification of the research is descriptive. Primary data were collected by interview. Type of interview used in this study using a free guided interview, is a combination of free and guided interview. ${ }^{9}$ Secondary data is data obtained from a review of the literature or the review of the literature or library materials related to the problem or research materials that are often referred to legal materials. ${ }^{10}$ Analysis of the data used in this research is the analysis of qualitative data that have been obtained from field studies and literature will be collected and systematically categorized and then analyzed qualitatively in order to obtain an overview and understanding of the systematic and comprehensive to address the problems examined.

\section{Results and Discussion}

\subsection{Implementation Deed of Establishment of Cooperative Development in Rembang}

Potency needscooperative societies will continue to increase, making the capital owners vying to establish cooperative enterprises. But today not all cooperatives in Indonesia are legal entities. Although cooperatives have not / not incorporated Law, but if managed / administered properly and professionally, many also exist and even thrive well and then had quite a lot of wealth. Only cooperatives so as not / is not incorporated then it is not possible to have a plot of land with Building Usage Right, and the deed of establishment and its amendment (if have the certificate of incorporation or articles of association) procedure or the procedure for amendment and / or replacement management is not necessarily in accordance with government regulations as the executor of the Act on cooperatives. ${ }^{11}$ Another case in terms of a cooperative that has been incorporated, then the start of the procedure for issuance of the deed of establishment and the changes to its Articles should definitely follow the procedure or procedures as stipulated in Government Regulation, as the executor of the Act on cooperatives. Cooperatives are already incorporated is possible to have the authority the right to have a plot of land with Building Usage Right.

Rembang is one district that has a considerable number of cooperatives. Based on the data source of as many as 572 cooperatives. Among the total number of these cooperatives there are only 200 active cooperatives. ${ }^{12}$ Some of the causes that led to many cooperatives are not active in Rembang is a cooperative for 3 years in a row are not reported financial statements, the cooperative who do not perform operational activities, in violation of the terms of internal and external cooperation and on the problems it is cooperative finally frozen. ${ }^{13}$

\footnotetext{
${ }^{9}$ Ibid, p. 84

${ }^{10}$ Mukti Fajar dan Yulianto, 2010, Dualisme Penelitian Hukum Normatif dan Empiris, Pustaka Pelajar, Yogyakarta, p. 156

11 Mulyoto, 2014, Pertanggungjawaban Notaris-PPAT dalam Menjalankan Tugas Jabatannya, Cakrawala Media, Yogyakarta, p.25

12 http://data.jatengprov.go.id, accessed 10 April 2019, 14:00 pm

${ }^{13}$ Interviews with staff Section of Supervision and Control Cooperative, Department of Industry, Trade Cooperatives and Small and Medium Enterprises (Dinindakopukm) Rembang, 5 April 2019
} 
In districts Apex Implementation Deed of Establishment of Cooperative Development is done by stages as follows, namely: ${ }^{14}$

\subsubsection{Preparation Phase Formation}

In accordance with the provisions of Article 3 (1) of the Regulation of the Minister of Cooperatives and Small and Medium Enterprises of the Republic of Indonesia Number 10 / Per / M.KUKM / IX / 2015 About Institutional Cooperative is a group of people who will form a cooperative shall understand the meaning, values and principles of cooperatives, family principles, the principles of legal entities and the principle of equity capital or equity. The formation of cooperatives must meet the requirements specified. As described in Article 3 (2).

\subsubsection{Preparation Phase Formation Meeting}

In this stage the founders must convene a preparatory meeting of the formation of cooperatives. Things that should be considered in the preparatory meeting of cooperative formation stage are:

- Prominent pioneers / founders of the cooperative office contact the cooperative office generally above level II level (district) to obtain an initial explanation of the procedures for establishing cooperative is good and right.

- Prominent pioneers such establishments should also have to submit a proposal on potential members and potential in the community area.

The top of the request, cooperative officials will provide counseling, among others, about the way of the formation of cooperatives is good and right. Those who intend to establish a cooperative must obtain information and counseling the broadest of the Cooperative Department officials in order to gain understanding and clarity regarding the purpose and objective of the establishment of cooperatives. Besides this, education and training should be done in advance for part or all of the applicants who will set up the cooperative. Having considered the notion and the foundation with confidence and awareness, without coercion or just went along with it, then they can hold a formation meeting. Meeting preparation and cooperative extension is expected to be attended by all potential members of the cooperative and this meeting led by pemarkasa money and will be accompanied by a cooperative that one level of cooperative founded. ${ }^{15}$ This stage is carried out under the provisions of Article 4 paragraph (1) and (2) of the Regulation of the Minister of Cooperatives and Small and Medium Enterprises of the Republic of Indonesia Number 10 / Per / M.KUKM / IX / 2015: ${ }^{16}$

\subsubsection{Phase Formation Meeting}

Meeting the formation of cooperatives referred to in led by the chairman of the meeting and a secretary appointed by the founders to discuss the main points of a draft constitution material. In this stage of the formation meeting to discuss matters relating to the formation of cooperatives, namely:

- Meeting was attended by a Notary cooperative formation. As stipulated in Article 12 paragraph (5).

\footnotetext{
${ }^{14}$ Ibid.

${ }^{15}$ Ibid.

${ }^{16}$ Regulation of the Minister of Cooperatives and Small and Medium Enterprises of the Republic of Indonesia Number 10 / Per / M.KUKM / IX / 2015
} 
- Notaries charge of recording the results of the discussion points were agreed at a meeting

- Meetings attended primary cooperative formation of at least 20 founders, while for secondary cooperatives attended by at least 3 legal entities. It is as set forth in Article 12 paragraph (1-2) of the Regulation of the Minister of Cooperatives and Small and Medium Enterprises of the Republic of Indonesia Number 09 of 2018 on the Implementation and Development of Cooperatives

- The results of the meeting of members of cooperative formation is made in several parts. As stipulated in Article 12 paragraph (4) of the Regulation of the Minister of Cooperatives and Small and Medium Enterprises of the Republic of Indonesia Number 09 of 2018 on the Implementation and Development of Cooperatives is the meeting of the establishment of cooperatives referred to) is made in the minutes of the meeting and / or 'meeting to draw up a draft Articles of Association.

\subsubsection{Phase Request for Obtaining Approval of Rights of Legal Cooperation}

After conducting a meeting stages of formation, the founders of the cooperative to prepare the deed of establishment to be submitted to the Notary. In a deed of establishment Notary use Legal Entity Administration System Cooperative (SISMINBHKO Legal Entity Administration System Cooperative (SISMINBHKOP) is an online service web based provided by the Ministry of Cooperatives and SMEs. This system aims to provide integrated services to the instigators of Cooperatives in Indonesia. SISMINBHKOP expected to provide convenience to the user (Notary) in conducting the filing SK cooperative legal entities and the process of change in the articles of association of cooperatives. Determination of the name of the cooperative as a result of the preparatory meetings of establishment can be done confirmation by a Notary on SISMINBHKOP. Cooperative which was approved names referred to in Article 8 shall apply for the Deed of Establishment within 30 (thirty) days. If after passing the 30 (thirty) days in the process of filing the name did not apply for the Deed of Establishment, the approval of the Cooperative through SISMINBHKOP name expire of Cooperatives shall propose a new name. ${ }^{17}$

On January 15, 2019 appeared a discourse about the delegation of authority endorsement of the Ministry of Cooperatives and SMEs to the Ministry of Justice and Human Rights of expansion will be implemented on 1 March 2019. However, due to yesterday's on 1 March 2019 and setup process integration validation system Cooperation between Ministry of Justice and Human Rights with the Ministry of cooperatives and SMEs has not been completed, based on the announcement of the Directorate General of Legal Administration (AHU) of the Ministry of Justice and Human Rights of the Republic of Indonesia, the ministry approve the deed of establishment of cooperatives, changes in the constitution of cooperatives, as well as the dissolution of the cooperative remains held at the Ministry of Cooperatives and SMEs to be more information on the transfer of these powers. Delay implementation of service validation, change and dissolution of the cooperative is made to provide maximum

\footnotetext{
${ }^{17}$ Article 12 paragraph (7-9) Regulation of the Minister of Cooperatives and Small and Medium Enterprises of the Republic of Indonesia Number 09 of 2018 on the Implementation and Development of Cooperatives
} 
service to the community and to avoid the problems that arise due to the completion of the discussion and the process of transferring the authority. ${ }^{18}$

\subsubsection{Phase Ratification Deed of Establishment}

At this stage the competent authority is the Department of Industry, Trade and SMEs conduct research on the material constitution and pngecekan to the existence of the cooperative. Cooperative received the submission will get Document Legalization Law Firm and Business License Savings and Loans / Unit Savings and Loans are made separately. This means that the proposed cooperative is valid as legal entities. Legal entities obtained enables cooperatives to carry out all legal proceedings including the ownership of land and buildings, as stipulated in the laws about agriculture, as well as doing business - a business that covers all areas of the economy. ${ }^{19}$ Article 9 of the Minister or the Authorized Officer's decision on the name to be included in the Deed of Establishment of Cooperative through SISMINBHKOP.

\subsection{As the role of Notary Deed of Establishment of Cooperative Enterprises in Rembang}

Notaries have the right authority / legal standing in a deed of incorporation of cooperatives. However, not all notaries have the authority to make the right deed of Cooperative Law. Notaries have the right / legal standing in a deed of incorporation of cooperatives are specific notary who had attended the briefing in a deed in connection with the cooperative legal entity and has had a certificate / license as a notary as Cooperation Deed Official (PPAK). ${ }^{20}$ Notary deed in cooperative use

Legal standing in the deed of incorporation associations are present in the Notary. Explanation of the Act No. 16 of 2001 on the Foundation, namely, that there is the arrangement of administration of an association incorporated under law, it can be done properly in order to prevent the issuing of a deed without going through the procedures as stipulated in the basic law of the Association, especially that which has been done in practice deed of incorporation association before approved by the Minister, also with the opening of Legal entity Administration System (SABH) as a means to access a bevy of incorporation until the issuance of Approval from the Minister, who has the authority to access rights are the Notary. ${ }^{21}$

SABH stands for Legal Entity Administration System or Sisminbakum, a computerized system in the process of issuance of the deed of establishment and approval Limited Liability Company Limited amendment. Sisminbakum is a form of public services provided by the Ministry of Justice and Human Rights of the Republic of Indonesia is now the Ministry of Justice and Human Rights, especially the Directorate General of Legal Administration in processing an application for issuance of the deed of establishment and the application for approval and acceptance / reporting changes in the articles of association of the Company Limited, which made online that can be

\footnotetext{
${ }^{18}$ https: // ahu.go.id, accessible 5April 2019, at 14:41 pm

${ }^{19} \mathrm{https} / / /$ santirahma.wordpress.com, accessible 5 April 2019, at 7:34 pm

${ }^{20}$ Mulyoto, 2016, Legal Standing, Cakrawala Media, Yogyakarta, p. 82

${ }^{21}$ Ibid, p. 83
} 
accessed by all notaries in Sisminbakum website. ${ }^{22}$ Enforcement of Legal Entity Administration System in the Directorate General of General Law Department of Justice and Human Rights of the Republic of Indonesia, SISMINBAKUM enacted in:

- Ratification of the certificate of incorporation or approval of amendment to statutes Company Limited

- Another petition, defined by decision of the Directorate General of Legal Administration. In the development including the issuance of the deed of establishment of the Foundation, Society and the application Approval of amendments of the Foundation / Association, as well as the receipt of the notification / report Data Foundation / Association.

With the online system, is expected to add to the Notary Deed Cooperative (NPAK) so that people can more easily and quickly in setting up the cooperative. ${ }^{23}$ Before using this system, the notary must make the process of registration or registration. Currently only Notary NPAK (or his representative) can use this system. If the Notaries SK NPAK not have, it can be submitted online through http://npak.depkop.go.id. ${ }^{24}$ Further to the deed of establishment of cooperatives can follow the stages that are already listed on the Legal Entity Administration System (SABH). ${ }^{25}$ Until the process on confirmation checkbox and click the Confirm button to apply. New application pf Cooperative Law Firm petition is completed. Staff Ministry of Cooperatives and SMEs will review and confirm approval / approval or rejection by email.

Approvalor refusal of requests for legal entity will be informed via e-mail, or can be monitored via the Dashboard Notary. Legal Entity application approval will be marked green icon. Rejection of the petition will be marked red icon. If it has been approved, click the button with the magnifying glass icon. To view details or download SK Legal Entity to be printed. If the petition is rejected, a notary may make improvements back, then raised and through the review process again. ${ }^{26}$ Legal standing in a deed of establishment of cooperatives are present in the Notary. This is a form of legal standing of the theory of legal authority. The authority granted by the Ministry of Cooperatives and Small and Medium Enterprises to the notary to assist in the process of making an authentic deed as proof that the cooperative established a valid legal entity, has the rule of law and recognized by the State. Making the deed of incorporation of a cooperative is a form of theoretical significance certainty of Community law not only need regulations to ensure legal certainty in their relations with one another, but it is also justice. A good law should meet the elements of fairness and certainty of Notary deed at the same time as the party is domiciled cooperative work by a code of ethics office and provide services to the public in the establishment, amendment and deed other certificates related to the activities of the

\footnotetext{
22 Subekti dan Mulyoto, 2014, Perkumpulan (Dalam Rangka Menyongsong lahirnya Undangundang Perkumpulan, Cakrawala Media, Yogyakarta, p. 51

${ }^{23}$ Interview with Fery Aryawan, Notary Deed Cooperative (NPAK) in Rembang, 5 April 2019

${ }^{24}$ Ministry of Cooperatives and Small and Medium Enterprises of the Republic of Indonesia, in 2017, Guidelines for Notaries and the Department, Legal Entity Administration System Cooperative (SISMINBHKOP) allow the ministry of the Republic of Indonesia, p. 2

${ }^{25}$ Ibid., p. 4

${ }^{26}$ Ibid, p. 9
} 
cooperative. Notary deed cooperative because of his position is the party responsible for the authenticity of the deed made. ${ }^{27}$

\subsection{Obstacles and solutions in the Deed of Establishment of Cooperative Development in Rembang}

The obstacles that will arise in the manufacture of the deed of establishment of cooperatives is not only derived from the notary, but also from the Department of Industry, Trade Cooperatives and Small and Medium Enterprises (Dinindakopukm) Rembang, and cooperatives themselves. The resistance of the cooperative is a member of the cooperative awareness level is still low, less managerial capacity, and limited capital resources. The resistance of the Notary Public Notary is still much limited knowledge of Notary Deed Official Cooperation (PPAK) and the low interest of the Notary Deed Cooperative (NPAK) in Rembang district were registered for the Legal Entity Administration System Cooperative (SISMINBHKOP). This has become an important task for the Department of Industry, Trade Cooperatives and Small and Medium Enterprises (Dinindakopukm) Rembang in order to further emphasize the importance of socialization associated with SISMINBHKOP continue to NPAK. With the state of a society, then the Office of Industry Trade Cooperatives and Small and Medium Enterprises (Dinindakopukm) Rembang should seek to build cooperation between the Notary in Rembang with the Agency's own cooperative.

\section{Closing}

\subsection{Conclusion}

Based on the description of the above discussion, the authors conclude the following:

- Implementation Deed of Establishment of Cooperative Development in Rembang is tahap preparation of formation, formation meeting preparation stage, the stage of the formation meeting, ratification proposal stage right legal entity Cooperation and validation phase Deed of Establishment

- As the role of Notary Deed of Establishment of Cooperative Enterprises in Rembang is as maker deed of cooperative efforts. Notaries have the right authority / legal standing in a deed of incorporation of cooperatives. Only notaries who have the right / legal standing in a deed of incorporation of cooperatives are specific notary who had attended the briefing in a deed in connection with the cooperative legal entity and has had a certificate / license as a Notary Public as Cooperation Deed Official (PPAK).

- Obstacles and solutions in the Deed of Establishment of Cooperative Development in Rembang derived from the cooperative is a member of the cooperative awareness level is still low, less managerial capacity, and limited capital resources. Barriers of Notary Public Notary is still much limited knowledge of Notary Deed Official Cooperation (PPAK) and the low interest of the Notary Deed Cooperative (NPAK) in Rembang district were registered for the Legal Entity Administration

\footnotetext{
${ }^{27}$ Seri Suharsa*, Lathifah Hanim, Peran Notaris Dalam Mewujudkan Badan Hukum Koperasi Melalui Transformasi Lembaga Keuangan Mikro Agribisnis (LKM-A) Di Kabupaten Temanggung, Jurnal Akta Vol. 4 No. 4 Desember 2017, p.783
} 
Volume 6 Issue 3, September 2019

System Cooperative (SISMINBHKOP). With the state of a society, then the Office of Industry Trade Cooperatives and Small and Medium Enterprises Rembang should seek to build cooperation between the Notaries in Rembang with the Agency's own cooperative.

\subsection{Suggestion}

- For the founders of the cooperative should be more active in seeking information relating to the establishment and management of a true cooperative, and more open to new information, so as not to miss the development of cooperatives as well as the rules of law are related.

- For Notary to be more careful, thorough, in registering online system in order to avoid data entry errors that can harm the applicant and the notary himself, besides notaries also have to be more enthusiastic in his duties as Cooperation Deed Official (PPAK).

- For the Department of Industry, Trade Cooperatives and Small and Medium Enterprises (Dinindakopukm) Rembang to be more active in emphasizing the importance of socialization to the Notary and cooperatives in order to walk in balance and alongside the appropriate laws and regulations in force.

4. References

[1] Abdul Ghofur Ansori, 2009, Lembaga Kenotariatan Indonesia (Perspektif Hukum dan Etika) UII Press, Yogyakarta

[2] Achmad Sulchan, Sukarmi, Ari Widiyanto, 2017, Akta Notaris Menggunakan Media elektronik, SINT Publishing, Semarang

[3] Amiruddin, 2012, Pengantar Metode Penelitian Hukum, Rajagrafindo Persada, Jakarta

[4] Andjar Pachta, 2007, Hukum Koperasi Indonesia Pemahaman,Rregulasi, Pendidikan, dan Modal Usaha, Kencana Prenada Media Group, Jakarta

[5] Azrul Tanjung, 2017, Koperasi dan UMKM sebagai Fondasi Perekonomian Indonesia, Erlangga, Jakarta

[6] Habib Adjie, 2003, Tebaran Pemikiran Dalam Dunia Notaris dan PPAT, "Penegakan Etika Profesi Notaris Dari Perspektif Pendekatan System, 'Lembaga Kajian Notaris dan PPAT Indonesia, Surabaya

[7] Kementerian Koperasi dan Usaha Kecil dan Menengah Republik Indonesia, 2017, Panduan untuk Notaris dan Dinas, Sistem Administrasi Badan Hukum Koperasi (SISMINBHKOP) Kementerian Koperasi dan UKM Republik Indonesia

[8] Mukti Fajar dan Yulianto, 2010, Dualisme Penelitian Hukum Normatif dan Empiris, Pustaka Pelajar, Yogyakarta

[9] Mulyoto, 2014, Pertanggungjawaban Notaris-PPAT dalam Menjalankan Tugas Jabatannya, Cakrawala Media, Yogyakarta

[10] Mulyoto, 2016, Legal Standing, Cakrawala Media, Yogyakarta

[11] N.G Yudara, Notaris dan Permasalahannya (Pokok-Pokok Pemikiran Di Seputar Kedudukan dan Fungsi Notari Serta Akta Notaris Menurut Sistem Hukum Indonesia). Majalah Renvoi Nomor 10.34 III, Edisi 3 Maret 2006,

[12] Ninik Widiyanto, 1992, Koperasi dan Perkonomian Indonesia, Rineka Cipta, Jakarta 
[13] Peraturan Menteri Koperasi dan Usaha Kecil dan Menengah Republik Indonesia Nomor 10/Per/M.KUKM/IX/2015

[14] Peraturan Menteri Koperasi dan Usaha Kecil dan Menengah Republik Indonesia Nomor 09 Tahun 2018 Tentang Penyelenggaraan dan Pembinaan Perkoperasian

[15] Seri Suharsa, Lathifah Hanim, "Peran Notaris Dalam Mewujudkan Badan Hukum Koperasi Melalui Transformasi Lembaga Keuangan Mikro Agribisnis ( LKM-A) Di Kabupaten Temanggung", in Jurnal Akta Vol. 4 No. 4 Desember 2017

[16] Sjaifurrachman, 2011, Aspek Pertanggungjawaban Notaris dalam Pembuatan Akta, Mandar Maju, Bandung

[17] Soerjono Soekanto dan Sri Mamadji, 2009, Penelitian Hukum Normatif: Suatu Tinjauan Singkat, RajaGrafindo Persada, Jakarta

[18] Subekti dan Mulyoto, 2014, Perkumpulan (Dalam Rangka Menyongsong lahirnya Undang-undang Perkumpulan, Cakrawala Media, Yogyakarta

[19] Tan Khong Kie (b), 2000, Buku II Studi Notarisat Serba Serbi Praktek Notaris, Cet 1, Ikhtiar Baru Van Hoeve, Jakarta 